\title{
Teaching NeuroImages: Melkersson-Rosenthal syndrome with permanent bilateral facial weakness
}

Fabian Rossi, MD, Nina Tsakadze, MD, Elisa M. Rossi, and Michael Hoffmann, MD

Neurology ${ }^{\circledR}$ 2019;92:e81. doi:10.1212/WNL.0000000000006683
Correspondence

Dr. F. Rossi

fabian.rossi@va.gov

Figure Patient with normal tongue, unable to kiss or smile
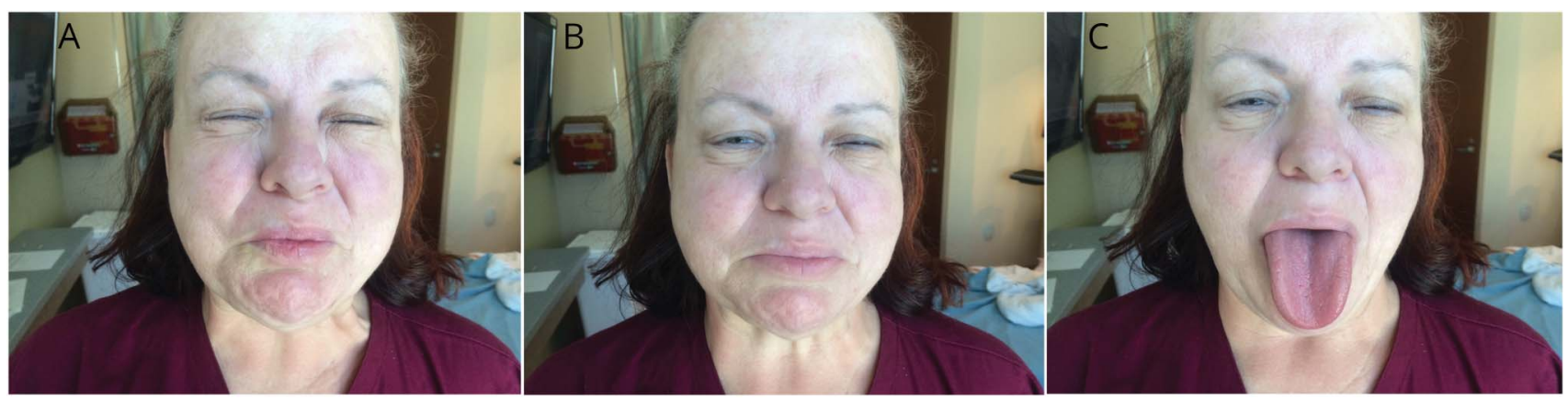

(A) Patient with mild bilateral facial edema unable to kiss. (B) Patient with mild bilateral facial edema unable to smile. (C) Normal tongue; no evidence of tongue plication.

A 56-year-old woman had multiple, alternating attacks of Bell palsy, associated with lower labial edema and dysgeusia. The facial paresis and edema resolved only partially, and over the years she lost the ability to smile and kiss, and developed lacrimation while eating (figure). Otherwise, neurologic examination, dermal examination, and brain MRI and magnetic resonance angiography were unremarkable. Family history was negative. Notable were negative serology for Lyme, sarcoidosis, HIV, and HbAlC elevation. Melkersson-Rosenthal is a rare syndrome presenting with a triad of alternating or bilateral facial weakness, macroglossia, and, less commonly, fissured tongue, with features sometimes permanent. ${ }^{1,2}$

\section{Author contributions}

Dr. Rossi: study concept and design, acquisition of data. Dr. Tsakadze, E.M.R., and Dr. Hoffman: analysis and interpretation data, design supervision, critical revision of manuscript for intellectual content.

\section{Study funding}

No targeted funding reported.

\section{Disclosure}

The authors report no disclosures relevant to the manuscript. Go to Neurology.org/ $\mathrm{N}$ for full disclosures.

\section{References}

1. Elias MK, Mateen FJ, Weiler CR. The Melkersson-Rosenthal syndrome: a retrospective study of biopsied cases. J Neurol 2013;260: $138-143$.

2. Liu R, Yu S. Melkersson-Rosenthal syndrome: a review of seven cases. J Clin Neurosci 2013;7:993-995. 


\section{Neurology}

\section{Teaching NeuroImages: Melkersson-Rosenthal syndrome with permanent bilateral facial weakness}

Fabian Rossi, Nina Tsakadze, Elisa M. Rossi, et al. Neurology 2019;92;e81

DOI 10.1212/WNL.0000000000006683

\section{This information is current as of December 24, 2018}

\section{Updated Information \&} Services

References

Subspecialty Collections

Permissions \& Licensing

Reprints including high resolution figures, can be found at: http://n.neurology.org/content/92/1/e81.full

This article cites 2 articles, 0 of which you can access for free at: http://n.neurology.org/content/92/1/e81.full\#ref-list-1

This article, along with others on similar topics, appears in the following collection(s):

Cranial neuropathy

http://n.neurology.org/cgi/collection/cranial_neuropathy

Information about reproducing this article in parts (figures,tables) or in its entirety can be found online at:

http://www.neurology.org/about/about_the_journal\#permissions

Information about ordering reprints can be found online:

http://n.neurology.org/subscribers/advertise

Neurology ${ }^{\circledR}$ is the official journal of the American Academy of Neurology. Published continuously since 1951, it is now a weekly with 48 issues per year. Copyright @ 2018 American Academy of Neurology. All rights reserved. Print ISSN: 0028-3878. Online ISSN: 1526-632X.

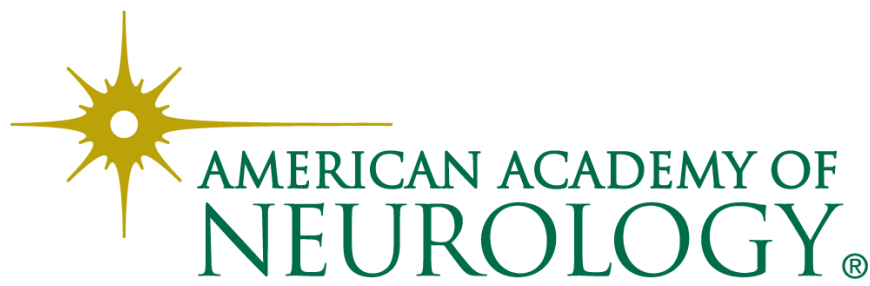

